\title{
The Age Influence On The Meat Quality
}

\author{
Urishbay Chomanov ${ }^{1}$, Weqar Sayed Mohammad ${ }^{2}$, Gulmira Kenenbay ${ }^{1}$, Aruzhan Shoman ${ }^{2}$
}

\begin{abstract}
The goat meat's total characteristic productivity for the efficiency of meat and features of its formation obtained from the quantity and quality of meat products. The purpose of slaughters control obtained the goat meat efficiency and Quality [1,2]. Based on the research, which studied in the "Ikram", farm in Almaty region has shown the result objectives of growth and development of animal. The factors which affect on the quality of goat meat according to the age dynamics are peculiarities of the formation of muscle, adipose tissue and internal organs, estimated food (biological value), consumption value of the goat meat and slaughter products. The above considering things are basis for the age dynamics.
\end{abstract}

Keywords - Chemical composition of the carcass meat, Fatty acid composition, Nutritional value of meat, Varietal Composition of the carcasses, Young goat.

\section{INTRODUCTION}

$\mathrm{T}$ HIS in the world we have seen the Reducing of organic food in human diet which is a big problem for human societies and specially a risk for the economy. Therefore the quality of foods (vegetable and animal) origin is high hygienic demands. The rough-haired goats are the largest of the goat meat breeds. The rough-haired are Black goat. The gradual increase seen in demand for goat products in the world in recent years has also shown its impact in Kazakhstan, especially Almaty Province. Goat breeding is a traditional sector of animal husbandry in Kazakhstan. Many private enterprises involved to keep various breeds of goats for different productivity trends in Kazakhstan. Natural and economic conditions of some areas of south-east Kazakhstan, particularly the Almaty region, also favor to their breeding, which makes goat a rearing livestock sector perspective. Currently, more than half of the total number of goats in Almaty region is rearing in private farms. The negative impact on the safety and productivity of goats, as well as other farm animals, has their conditions of detention, to a greater extent

1 Urishbay Chomanov, is member of the NAS Academy, professor, doctor with «The Kazakh scientific research institute overworking and the foodprocessing industry» Ltd Almaty, Kazakhstan, (e-mail: chomanov_u@mail,ru).

2 Weqar Sayed Mohammad is Master student in Kazakh National Agrarian University.

3Gulmira Kenenbay is $\mathrm{PhD}$ with «The Kazakh scientific research institute overworking and the food-processing industry» Ltd Almaty, Kazakhstan, (corresponding author's phone: +7(727) 3960419; fax: +7(727) 3960419; email: gkenenbay@mail.ru).

4 Aruzhan Shoman is $\mathrm{PhD}$ student in Kazakh National Agrarian University. e- mail: shoman_aruzhan@mail.ru. determined by the environmental conditions in the region of their breeding. The consequence of human economic activity is usually the changes in natural composition of the environment [1].

The purpose of this study is to know the possible ecological safety factors of goat's raw meat.

\section{MATERIAL AND METHOD OF THE STUDY}

Experimental part of the work is carried out in the private sector, "Ikram" Almaty region, where it was established, and focused for the most highly productive breeding herd of Kazakh rough-haired goats. Growth \& Development of young animals, and studied the results of weighing at birth, 4,8 and 12 months. In addition, we measured the following eight characteristics the goat for exterior body measurements. Meat productivity was studied through the control of slaughter animals. At the same time determined slaughter live weight of an individual weighing after 24-hour exposure hungry. The economic effectiveness of breeding determined by comparing the proceeds of realized production. Maintenance and feeding of goats at the farm is organized according to the year-round grazing system, which allows maximum use of the natural forage lands.

Our scientific and economic experience was conducted:

1 - goats 4 months of experimental group

2-control group 8 months

3 - the control group 12 months.

\section{RESEARCH RESULTS}

The goat meat's total characteristic productivity for the efficiency of meat and features of its formation obtained from the quantity and quality of meat products. The purpose of slaughters control obtained the goat meat efficiency and Quality [1,2]. Slaughter results showed that goats can be referred to quite precocious animals. So, the slaughter weight of the goat meat during the period from 4 months to one year old increased $23.83 \mathrm{~kg}$, or $44.37 \%$, and the buck carcass weight were $11.15 \mathrm{~kg}$, or $39.57 \%$. Slaughter output at the age of 4 months was $41.59 \%$, when during the 12 months increased to $44.59 \%$. Crude fat content in the carcasses of goats were also $0.74 \mathrm{~kg}$ or $85.06 \%$, increased during 4 to 12 months, and the fat output - from 0.75 to $2.11 \%$. Meat carcasses can be judged by cross sectional area of the longissimus dorsal muscle. Our data clearly shows that, the figure of 8 months reached to $46.92 \%$ and the 12 months raised up to $-62.83 \%$. For the most complete characteristic 
meat quality of goats in the age dynamics need to analyze the morphological composition of carcasses. Increase in mass cuts of the first grade depends directly on the intensive development of muscle tissue and intramuscular fat [3,7]. The research results varietal composition of carcasses is summarized in Tabl. I.

Table1. Varietal Composition of the Goat carcasses $(n=3)$ (Appendix)

According to the data Table 1 shows that older observed stable increasing proportion of the 1st grade (loin) cuts and 2nd grade output of (loin) cuts decreased more than 5\%. Also we presented Bone and connective tissue masses output in Table 2. Carcasses of 8 and 12-month-old animals have nearly the same ratio of flesh (pulp) with little difference of $0.4 \%$ and the 4-month-old animals difference was 2.56 or $2.96 \%$, in the yield of bone and cartilage were 0.39 , respectively, 2.53 to $2.92 \%$.

Nutritional value of the meat main part is flesh, which includes muscle and fat tissue. Therefore, special important study of the chemical composition of meat carcass is one of the main indicators for the quality of meat products (Table II, Appendix).

Chemical composition analysis results of the experimental goats flesh carcasses medium samples indicate physiological maturity of the meat. (Table III, Appendix)

A very important feature of meat indicator is its biological value. Because protein is evaluative and qualitative index (BCP), of muscle tissue (Table IV)the "References" style.

TABLE IV.

BIOLOGICAL VALUE OF THE MEAT ( $\mathrm{N}=3$ )

\begin{tabular}{|l|l|l|l|}
\hline \multirow{2}{*}{$\begin{array}{l}\text { Age of } \\
\text { animal } \\
\text { by } \\
\text { months }\end{array}$} & Amino acid content, $\mathrm{mg} \%$ & $\begin{array}{l}\text { Protein } \\
\text { quality } \\
\text { indicator }\end{array}$ \\
\hline 4 & $229,58 \pm 1,53$ & $61,14 \pm 0,19$ & 3,75 \\
\hline 8 & $247,09 \pm 0,33$ & $60,52 \pm 0,15$ & 4,08 \\
\hline 12 & $253,33 \pm 0,46$ & $60,11 \pm 0,05$ & 4,21 \\
\hline
\end{tabular}

We observed tryptophan levels increase $7,9 \%$ in the carcass of animal, which had 4 to 8 months of age and from 8 to 12 months of age animals carcass' tryptophan level was $2.6 \%$. Hydroxyproline content from 4 to 8 months was reduced $1.01 \%$, and from 8 to 12 months was $0.68 \%$. Physicalchemical examination and fatty acid composition of fat in the experimental goats, study of physical-chemical parameters of carcass fat of experimental goats showed that the amount of moisture in their fat decreases with aging. Thus, in the animals in age of 4 months it was 1.44 times greater than that of 8month animals, and 1.65 times than that of the 12-month-old. The content of total lipids in the fat on contrary was the least at 4-month-old goats, has significantly increased to 8 and 12 months. Fluctuations in the melting point and iodine value of the fat in the experimental animals were minor under one year old. Nutritional value of fat which contained in the body of goats under study is determined by its composition. Farm animal tissues contain fatty acids mainly of various lipids and only 1-3\% of them are in Free State, in the animal tissue fatty acid composition is closely related to their structure and functional metabolic activity. Due to the fact that fatty acids play an important role in the formation of tissues, growth of young goats, intermediate metabolism, reproduction, there was an urgent necessity to study their maintenance in the lipids of muscle and adipose tissues of goats from different age groups $[3,4]$. The subcutaneous fat and muscle tissue fat of goats at the age of 4 and 8 months, contents of unsaturated fatty acids ranged from $40-43 \%$ up to 52 , saturated from 47 to $56-59,4 \%$. The factors of correlation amounted to 1,1-0,88 units. Subcutaneous fat in animals of all ages contains palmitoleic and oleic acid larger amount than other types of fat. The ratio of unsaturated to saturated fatty acids in the internal fat significantly decreased by lowering proportion of the monounsaturated and polyunsaturated acids, and increasing the proportion of saturated. Difference between subcutaneous and internal fat are that the internal fat contains more saturated fatty acids, especially stearic and palmitic, and somewhat less unsaturated. Especially low proportion $(0,52-1,626 \%)$ of polyunsaturated fatty acids, for example essential linoleic acid which 4.3-4.5 times less than saturated fat. The content of saturated fatty acids at the fat of domestic goats of all the three age groups was approximately at the same level. The maximum divergence ranged from 3.77 to $8 \%$ in favor of 12 month age compared with the 4-month-old. In the muscle tissue fat percentage of saturated fatty acids was significantly less. But Majority was mono- and polyunsaturated. The main fatty acids of muscle tissue lipids of the goats are: oleic, palmitic, stearic, palmitoleic. Fatty acid spectrum of muscle tissue is highly variable to animal's age. When we 12 month age goats compared with 4-months age the 12 month age goat saturated fatty acids concentration were significantly (capric 1.45 times, lauric - 4.18 times, palmitic - 1.26 times, stearic 1.2 times, arachidic - 4.08 times, higher, and unsaturated, conversely (palmitoleic - 1.52 times, oleic - 1.18 times, linoleic - 1.88 times, linolenic - 2.65 times. specific content of oleic acid 36,15-42,99\% and palmitic-1,71-2,61\%.) was less. The amount of saturated fatty acids significantly decreases in the goats muscle tissue fats which concern to the age. In the muscle tissue lipids of four months old goats indispensable (essential) linolenic acid was 1.5 times greater than in the meat of 8-months goats and 2.6 times higher from the meat of 12-months goats [5]. During all period of age goat have better ratio of unsaturated acids distinguished with saturated acids: in the 4 months of age, it was 1.1 also at the 8-months - 0.95, and at 12 months - 0.68, which is an advantage for this type of indication and its meat quality.

\section{CONCLUSION}

Obtained data on the study of meat efficiency of young goats, show that the goat carcasses fatty acid composition are 
well balanced. Monitoring the growth and development of young Russian breed goats showed that the animal organism develops most intensively up to 4 month age; during this time absolute growth rate received maximum 117 grams per day. Age effect of the young Russian goat breeds founded after the quality products of slaughter by complex indicators and compared 8monts animals with the 4 months optimal slaughter yield (from 41.59 to $43.17 \%$ ), increasing output cuts (loin) of the 1 grade (from 81.83 up to $83.58 \%$ ) and the eye muscular area (from 11.06 to $16.25 \mathrm{~cm} 2$ ). Study on the chemical composition of muscle tissue shown that the increasing of the animals age reduce the moisture content in meat (from 76.67 up to $71.36 \%$ ) and increased the mass fraction of solids (from 23.33 up to $28.64 \%$ ) [6]. Character of adipose tissue synthesis is due to the age of goats. According to increasing the animal's age from 4 to 12 months, that increase the amount of extractable mentioned fat $19,24 \%$, and melting temperature 1 , $5{ }^{\circ} \mathrm{C}$ and reduce the iodine value to 2.15 .for the rearing of Russian goat herds evidence of the environment are necessary, and regular monitor "the air - soil - water - food - biological material - products" for the purpose of biotechnological chain, and to determine the level of contamination of feed and production of heavy metals. In order to generate high quality and environmentally safe products in the influence zones the major industrial centers should be sell Russian advisable young goats breed for meat not older than 8 months

\section{REFERENCES}

[1] Mandakh B., Vozagdsuren, Nadmid N. / Effects of genotype, sex and age on the fibre quality of Mongolian goats / Newsletter of the European Fine fibre Network, 1996. N6:26-28.

[2] Jerry Laker Conference Report: VI International Conference on goats, Berjing / Newsletter of the European fine fibre Network, 1996, N6:2930.

[3] Ma Ning, Li Uongjun, Song Vagin, Luan Weimin. Estimates of nongenetic parameters of main traits in Liaoning cashmer goats / Newsletterof the European Fine fibre Network, 1995, N5:19-22.

[4] Parthasarathy M. Goats in New Zealand /J. Agriculture. 1983. 147.5:3031.

[5] Tohnson T.L. Cashmere from Australia / J. Agriculture. 1985. 26.1:3-6.

[6] Chet R.U. Fine fibre production in high Mountain and Trans-Himalayan region of Nepal / Newsletter of the European Fine fibre Network, 1998. N3. 12 p.

[7] Anon. Refltater fra gietekontrollen // Sau Geit., -1985, 38.4:196-197.

APPENDIX

TABLE I

VARIETAL COMPOSITION OF THE GOAT CARCASSES $(\mathrm{N}=3$ )

\begin{tabular}{|c|c|c|c|c|c|c|}
\hline \multirow{3}{*}{$\begin{array}{l}\text { Chop } \\
\text { off } \\
\text { Loin } \\
\text { (Cuts) }\end{array}$} & \multicolumn{6}{|c|}{4 months } \\
\hline & \multicolumn{2}{|c|}{ Flesh meat } & \multicolumn{2}{|c|}{$\begin{array}{ll}\text { bone } & \text { and } \\
\text { cartilage } & \end{array}$} & \multicolumn{2}{|c|}{ Cut(loin) } \\
\hline & $\begin{array}{l}\text { mass, } \\
\mathrm{kg}\end{array}$ & $\begin{array}{l}\% \text { of } \\
\text { weig } \\
\text { ht } \\
\text { cuts }\end{array}$ & $\begin{array}{l}\text { mas } \\
\mathrm{s}, \mathrm{kg}\end{array}$ & $\begin{array}{l}\% \text { of } \\
\text { weight } \\
\text { loin } \\
\text { (cuts) }\end{array}$ & $\begin{array}{l}\text { mass, } \\
\mathrm{kg}\end{array}$ & $\begin{array}{l}\% \text { of } \\
\text { weight } \\
\text { carcass } \\
\text { (masca } \\
\text { ra) }\end{array}$ \\
\hline
\end{tabular}

\begin{tabular}{|c|c|c|c|c|c|c|c|}
\hline 1 grade & $\begin{array}{l}4,392 \\
\pm \\
0,21\end{array}$ & $\begin{array}{l}73,51 \\
0 \quad \pm \\
2,71\end{array}$ & $\begin{array}{l}1,50 \\
1 \pm \\
0,07\end{array}$ & \multicolumn{2}{|c|}{$\begin{array}{l}25,140 \\
\pm 1,71\end{array}$} & $\begin{array}{l}5,973 \\
\pm \\
0,11 \\
\end{array}$ & $\begin{array}{l}81,830 \\
\pm 0,40\end{array}$ \\
\hline 2 grade & $\begin{array}{l}0,892 \\
\pm \\
0,05\end{array}$ & $\begin{array}{l}67,19 \\
0 \pm \\
\pm \\
0,97\end{array}$ & $\begin{array}{l}0,43 \\
5 \quad \pm \\
0,01\end{array}$ & \multicolumn{2}{|c|}{$\begin{array}{l}32,810 \\
\pm 0,97\end{array}$} & $\begin{array}{l}1,327 \\
\pm \\
0,61\end{array}$ & $\begin{array}{l}18,170 \\
\pm 8,50\end{array}$ \\
\hline \multicolumn{8}{|c|}{8 months } \\
\hline 1 grade & $\begin{array}{l}8,751 \\
\pm \\
0,63\end{array}$ & $\begin{array}{l}74,5 \\
6 \pm \\
3,79\end{array}$ & $\begin{array}{l}2, \\
97 \\
8 \\
\pm \\
0 \\
39 \\
\end{array}$ & $\begin{array}{l}25 \\
440 \\
\pm \\
3,7 \\
9\end{array}$ & \multicolumn{2}{|c|}{$\begin{array}{l}11,730 \pm \\
0,25\end{array}$} & $\begin{array}{l}83,580 \\
\pm 0,70\end{array}$ \\
\hline 2 grade & $\begin{array}{l}1,150 \\
\pm \\
\pm \\
0,20\end{array}$ & $\begin{array}{l}50,9 \\
40 \pm \\
\pm \\
8,68\end{array}$ & $\begin{array}{l}1, \\
10 \\
7 \\
\pm \\
\pm \\
0, \\
19 \\
\end{array}$ & $\begin{array}{l}49 \\
060 \\
\pm \\
\pm \\
0,8 \\
7\end{array}$ & \multicolumn{2}{|c|}{$\begin{array}{l}2,257 \pm \\
\pm 0,02\end{array}$} & $\begin{array}{l}16,090 \\
\pm \\
\pm 0,34\end{array}$ \\
\hline \multicolumn{8}{|c|}{12 months } \\
\hline 1 grade & $\begin{array}{l}11,89 \\
4 \\
\pm \\
0,06\end{array}$ & $\begin{array}{l}74,0 \\
20 \\
\pm \\
0,72\end{array}$ & $\begin{array}{l}4, \\
17 \\
6 \\
\pm \\
0, \\
14 \\
\end{array}$ & $\begin{array}{l}25 \\
980 \\
\pm \\
0,7 \\
2\end{array}$ & \multicolumn{2}{|c|}{$\begin{array}{l}16,070 \\
\pm 0,10\end{array}$} & $\begin{array}{l}87,090 \\
\pm 0,34\end{array}$ \\
\hline 2 grade & $\begin{array}{l}1,195 \\
\pm \\
0,75\end{array}$ & $\begin{array}{l}50,1 \\
30 \\
\pm \\
2,18\end{array}$ & $\begin{array}{l}1, \\
18 \\
8 \\
\pm \\
0 \\
05 \\
\end{array}$ & $\begin{array}{l}49 \\
870 \\
\pm \\
2,1 \\
8\end{array}$ & \multicolumn{2}{|c|}{$\begin{array}{l}2,383 \\
\pm 0,08\end{array}$} & $\begin{array}{l}12,910 \\
\pm 0,34\end{array}$ \\
\hline
\end{tabular}


TABLE II

CHEMICAL COMPOSITION AND NUTRITIONAL VALUE OF MEAT CARCASSES OF EXPERIMENTAL GOATS $(\mathrm{N}=3)$

\begin{tabular}{|c|c|c|c|c|c|c|c|}
\hline \multirow{3}{*}{$\begin{array}{ll}\text { Age of } \\
\text { animal by } \\
\text { months }\end{array}$} & \multicolumn{5}{|l|}{ Content, $\%$} & \multirow{3}{*}{$\begin{array}{l}\mathrm{pH} \text { of } \\
\text { the } \\
\text { meat }\end{array}$} & \multirow{3}{*}{$\begin{array}{lr}\text { The energy } \\
\text { value } & 100 \\
\text { grams } & \text { of } \\
\text { meat, kcal }\end{array}$} \\
\hline & \multirow{2}{*}{ moisture } & \multirow{2}{*}{$\begin{array}{l}\text { dry } \\
\text { matter }\end{array}$} & \multicolumn{3}{|c|}{ Comprise or contain as part of a whole. } & & \\
\hline & & & fat & protein & ash & & \\
\hline 4 & $76,67 \pm 0,26$ & 23,33 & $2,68 \pm 0,21$ & $19,53 \pm 0,06$ & $1,12 \pm 0,01$ & 5,6 & 105,0 \\
\hline 8 & $74,54 \pm 0,25$ & 25,46 & $4,12 \pm 0,06$ & $20,21 \pm 0,18$ & $1,13 \pm 0,01$ & 5,7 & 121,2 \\
\hline 12 & $71,36 \pm 0,11$ & 28,64 & $5,19 \pm 0,15$ & $22,31 \pm 0,26$ & $1,14 \pm 0,01$ & 5,9 & 139,7 \\
\hline
\end{tabular}

TABLE III

MORPHOLOGICAL COMPOSITION OF THE CARCASSES OF EXPERIMENTAL GOATS $(\mathrm{N}=3)$

\begin{tabular}{|c|c|c|c|c|c|c|}
\hline \multicolumn{7}{|l|}{4 months } \\
\hline \multirow[t]{2}{*}{ Loin (cut) } & \multicolumn{2}{|l|}{ Flesh (pulp) } & \multicolumn{2}{|c|}{ Bones and cartilages } & \multicolumn{2}{|c|}{ The loin (cuts) } \\
\hline & Weight, kg & $\begin{array}{l}\% \text { of the } \\
\text { loin(cut) } \\
\text { weight }\end{array}$ & Weight, kg & $\begin{array}{l}\% \text { of the } \\
\text { loin(cut) } \\
\text { weight }\end{array}$ & Weight, kg & $\begin{array}{l}\% \text { of the } \\
\text { loin(cut) } \\
\text { carcasses }\end{array}$ \\
\hline spinal scapular & $\begin{array}{l}1,972 \\
0,115\end{array}$ & $\begin{array}{ll}73,62 & \pm \\
0,800 & \end{array}$ & $\begin{array}{l}0,706 \\
0,015\end{array}$ & $\begin{array}{ll}26,38 & \pm \\
0,800 & \end{array}$ & $\begin{array}{l}2,714 \\
0,129\end{array}$ & $36,68 \pm 0,41$ \\
\hline hip (coxofemoral) & $\begin{array}{l}1,843 \\
0,028\end{array}$ & $\begin{array}{l}77,52 \\
2,577\end{array}$ & $\begin{array}{l}0,535 \\
0,073\end{array}$ & $\begin{array}{l}22,48 \\
2,577\end{array}$ & $\begin{array}{l}2,378 \\
0,058\end{array}$ & $32,60 \pm 0,21$ \\
\hline lumbar & $\begin{array}{l}0,657 \\
0,047\end{array}$ & $\begin{array}{l}71,66 \\
2,744\end{array}$ & $\begin{array}{l}0,259 \\
0,016\end{array}$ & $\begin{array}{l}28,34 \\
2,744\end{array}$ & $\begin{array}{l}0,905 \\
0,032\end{array}$ & $12,55 \pm 1,23$ \\
\hline fore shank & $\begin{array}{l}0,132 \\
0,012\end{array}$ & $\begin{array}{l}57,91 \\
2,380\end{array}$ & $\begin{array}{l}0,096 \\
0,001\end{array}$ & $\begin{array}{l}42,09 \\
2,380\end{array}$ & $\begin{array}{l}0,228 \\
0,011\end{array}$ & $3,12 \pm 0,09$ \\
\hline forearm & $\begin{array}{l}0,682 \\
0,024\end{array}$ & $\begin{array}{l}72,78 \\
1,278\end{array}$ & $\begin{array}{l}0,255 \\
0,008\end{array}$ & $\begin{array}{l}27,22 \\
1,278\end{array}$ & $\begin{array}{l}0,912 \\
0,017\end{array}$ & $12,83 \pm 0,20$ \\
\hline shank & $\begin{array}{l}0,078 \\
0,017\end{array}$ & $\begin{array}{l}47,98 \\
0,629\end{array}$ & $\begin{array}{l}0,084 \\
0,016\end{array}$ & $\begin{array}{l}52,02 \\
0,629\end{array}$ & $\begin{array}{l}0,163 \\
0,033\end{array}$ & $2,22 \pm 0,47$ \\
\hline whole carcass & $\begin{array}{l}5,364 \\
0,235\end{array}$ & $\begin{array}{l}73,46 \\
1,544\end{array}$ & $\begin{array}{l}1,936 \\
0,068\end{array}$ & $\begin{array}{l}26,54 \\
1,544\end{array}$ & $\begin{array}{l}7,300 \\
0,167\end{array}$ & $\begin{array}{l}100,00 \quad \pm \\
0,00\end{array}$ \\
\hline \multicolumn{7}{|l|}{8 months } \\
\hline spinal scapular & $\begin{array}{l}4,299 \\
0,298\end{array}$ & $69,9 \pm 0,88$ & $\begin{array}{l}1,626 \\
0,256\end{array}$ & $30,06 \pm 0,88$ & $\begin{array}{l}5,925 \\
0,065\end{array}$ & $42,22 \pm 0,41$ \\
\hline hip (coxofemoral) & $\begin{array}{l}3,423 \\
0,276 \\
\end{array}$ & $75,3 \pm 1,14$ & $\begin{array}{l}0,937 \\
0,239 \\
\end{array}$ & $24,66 \pm 1,14$ & $\begin{array}{l}4,360 \\
0,037 \\
\end{array}$ & $31,07 \pm 0,21$ \\
\hline lumbar & $\begin{array}{l}1,029 \\
0,076\end{array}$ & $73,9 \pm 0,30$ & $\begin{array}{l}0,416 \\
0,116\end{array}$ & $26,09 \pm 0,30$ & $\begin{array}{l}1,445 \\
0,191\end{array}$ & $10,29 \pm 1,23$ \\
\hline fore shank & $\begin{array}{l}0,299 \\
0,019\end{array}$ & $63,4 \pm 0,42$ & $\begin{array}{l}0,192 \\
0,022\end{array}$ & $36,62 \pm 0,42$ & $\begin{array}{l}0,491 \\
0,016\end{array}$ & $3,50 \pm 0,09$ \\
\hline forearm & $\begin{array}{l}0,717 \\
0,223\end{array}$ & $65,1 \pm 0,59$ & $\begin{array}{l}0,584 \\
0,231\end{array}$ & $34,86 \pm 0,59$ & $\begin{array}{l}1,301 \\
0,034\end{array}$ & $9,27 \pm 0,20$ \\
\hline shank & $\begin{array}{l}0,134 \\
0,039\end{array}$ & $23,4 \pm 2,34$ & $\begin{array}{l}0,330 \\
0,084\end{array}$ & $76,58 \pm 2,34$ & $\begin{array}{l}0,464 \\
0,061\end{array}$ & $3,31 \pm 0,47$ \\
\hline whole carcass & $\begin{array}{l}9,902 \\
0,445\end{array}$ & $70,5 \pm 2,10$ & $\begin{array}{l}4,085 \\
0,226\end{array}$ & $29,46 \pm 2,10$ & $\begin{array}{l}14,033 \\
0,212 \\
\end{array}$ & $\begin{array}{ll}100,00 \quad \pm \\
0,00\end{array}$ \\
\hline \multicolumn{7}{|l|}{12 months } \\
\hline spinal scapular & $\begin{array}{l}6,229 \\
0,130\end{array}$ & $70,7 \pm 1,07$ & $\begin{array}{l}2,587 \\
0,079\end{array}$ & $29,35 \pm 1,07$ & $\begin{array}{l}8,816 \\
0,051\end{array}$ & $47,78 \pm 0,65$ \\
\hline hip (coxofemoral) & $\begin{array}{l}4,286 \\
0,050\end{array}$ & $77,9 \pm 0,36$ & $\begin{array}{l}1,217 \\
0,039\end{array}$ & $22,11 \pm 0,36$ & $\begin{array}{l}5,502 \\
0,088\end{array}$ & $29,82 \pm 0,25$ \\
\hline
\end{tabular}


Int'I Journal of Research in Chemical, Metallurgical and Civil Engg. (IJRCMCE) Vol. 4, Issue 1 (2017) ISSN 2349-1442 EISSN 2349-1450

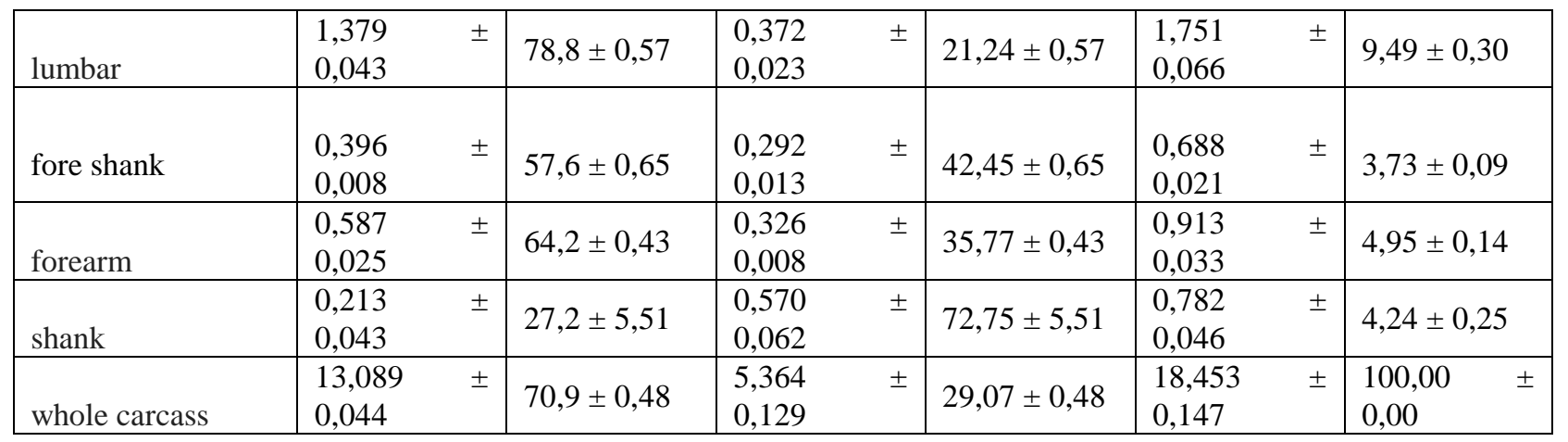

